\title{
Pemanfaatan Media Sosial Instagram untuk Meningkatkan Pengetahuan Remaja Tentang Pubertas
}

\author{
Hariyani Sulistyoningsih*1, Sinta Fitriani ${ }^{2}$ \\ 1,2Program Studi S1 Kesehatan Masyarakat Sekolah Tinggi Ilmu Kesehatan Respati \\ *e-mail: yanstia 77@yahoo.co.id 1, taniesa1571@gmail.com ${ }^{2}$
}

\begin{abstract}
Adolescents need accurate information about puberty, because adolescents who fail to go through the puberty phase may experience psychological disorders that have an impact on the next phase of life. This service activity is carried out to disseminate information on puberty by utilizing Instagram media. The specific purpose of this activity is to make adolescents understand the definition of puberty, when puberty occurs, changes that generally occur during puberty and the correct attitude in dealing with puberty. The method is the delivery of material directly through social media. Activities carried out in three stages, namely: planning, implementation and reflection. Planning includes material preparation and socialization of activities; implementation includes the delivery of information through live broadcasts using Instagram, starting with the presentation of the material, followed by answering questions. The last stage is reflection, namely analyzing the responses of the participants. Participants responded very well, as evidenced by a number of questions and statements of support that were delivered during the activity. Dissemination of information for adolescents as well as parents through online media needs to continue, especially during the period of limiting activities due to the pandemic.
\end{abstract}

Keywords: Youth, Puberty, Knowledge

\begin{abstract}
Abstrak
Remaja memerlukan informasi tepat tentang pubertas, karena remaja yang gagal melalui fase pubertas bisa jadi mengalami gangguan psikologis yang berdampak pada fase kehidupan selanjutnya. Kegiatan pengabdian ini dilakukan untuk menyebarluaskan informasi pubertas dengan memanfaatkan media Instagram. Tujuan khusus kegiatan ini adalah agar remaja memahami definisi pubertas, kapan terjadinya pubertas, perubahan yang umum terjadi selama pubertas serta sikap yang tepat dalam menghadapi pubertas. Metode berupa penyampaian materi secara langsung melalui media sosial. Kegiatan dilakukan melalui tiga tahap yaitu: perencanaan, pelaksanaan dan refleksi. Perencanaan meliputi persiapan materi serta sosialisasi kegiatan; pelaksanaan meliputi penyampaian informasi melalui siaran langsung menggunakan instagram, diawali dengan pemaparan materi, dilanjutkan menjawab pertanyaan. Tahap terakhir adalah refleksi yaitu menganalisis respon peserta. Respon peserta sangat baik, dibuktikan dengan sejumlah pertanyaan dan pernyataan dukungan yang disampaikan selama kegiatan. Penyebarluasan informasi bagi remaja juga orang tua melalui media online perlu terus dilakukan terlebih dimasa pembatasan aktivitas karena pandemi..
\end{abstract}

Kata kunci: Remaja, Pubertas, Pengetahuan

\section{PENDAHULUAN}

Remaja adalah mereka yang berusia 11 sampai 24 tahun dan belum menikah, dimana terjadi tanda-tanda penyempurnaan perkembangan jiwa. Masa remaja merupakan peralihan dari masa kanak-kanak menuju dewasa, bukan hanya secara fisik namun juga psikologis (Sarwono, 2016). Salah satu kondisi yang dialami remaja adalah pubertas, yaitu periode dimana seseorang mencapai kematangan fungsi seksual sehingga telah siap melakukan fungsi reproduksi (Tim Penulis Komupedia, 2020).

Remaja yang berada pada masa pubertas akan mengalami berbagai perubahan fisik, baik primer maupun sekunder. Berbagai perubahan fisik yang terjadi jika tidak dipahami dengan baik akan menyebabkan remaja merasa malu, bingung, bahkan minder dan tidak percaya diri. Hal ini tidak akan terjadi jika remaja memiliki bekal pengetahuan yang cukup sehingga memahami perubahan yang terjadi dan mampu bersikap positif ketika memasuki 
pubertas. Selanjutnya adalah apa yang dilakukan untuk memberikan bekal informasi kepada remaja?

Kegagalan remaja dalam melalui masa pubertas dapat menyebabkan gangguan psikologis yang akan berdampak pada fase kehidupan selanjutnya. Tidak sedikit remaja yang memiliki pengetahuan yang kurang tentang pubertas, seperti halnya hasil penelitian di SMPN 13 Sijunjung yang menunjukkan bahwa 30\% siswa laki-laki dan 35,4\% siswa perempuan masih memiliki pengetahuan yang kurang terkait pubertas (Juliana et al., 2014). Hal ini juga selaras dengan data di SMPN 8 Kediri yang menunjukkan bahwa terdapat 47,4\% siswa yang memiliki pengetahuan yang kurang terkait pubertas. Pengetahuan mengenai pubertas adalah hal yang penting bagi remaja karena pengetahuan yang cukup diharapkan dapat membantu remaja mengenal perubahan yang terjadi sehingga lebih siap menghadapi pubertas. Kurangnya pengetahuan akan berdampak pada sikap dan perilaku remaja saat menjalani masa pubertas (Subekti et al., 2020).

Pengetahuan remaja dapat diperoleh melalui informasi yang disampaikan dengan berbagai metode, salah satunya adalah penyuluhan dengan dengan beragam bentuk dan media, disesuaikan dengan kebutuhan dan kondisi. Penyuluhan merupakan kegiatan mendidik individu ataupun kelompok yang dilakukan secara nonformal untuk memberi pengetahuan, informasiinformasi dan berbagai kemampuan agar dapat membentuk sikap dan perilaku hidup yang lebih baik seperti yang diharapkan. Terdapat berbagai metode yang dipilih dalam melakukan penyuluhan, disesuaikan dengan tujuan dan jumlah sasaran. Salah satu metode yang dapat dipilih adalah penyuluhan massa (Notoatmodjo, 2012).

Beberapa hasil penelitian menunjukkan bahwa penyuluhan dapat berpengaruh terhadap pengetahuan. Penelitian terhadap siswa SMAN 6 Pontianak menunjukkan bahwa terdapat perbedaan skor pengetahuan siswa sebelum dan sesudah mengikuti penyuluhan (Buzarudina, 2013). Kegiatan pengabdian masyarakat berupa penyuluhan yang dilakukan melalui tatap muka secara langsung dengan siswa remaja putri di SMPN 2 Gamping Sleman juga menunjukkan terdapat perbedaan signifikan kemampuan siswa dalam menjalani pubertas sebelum dan sesudah mengikuti penyuluhan (Dewi et al., 2019). Selain dengan tatap muka langsung, terdapat berbagai media yang dapat dimanfaatkan untuk memberikan informasi. Salah satu media yang dapat dimanfaatkan untuk menyebarkan informasi adalah media sosial, terlebih di masa pandemi Covid dimana aktivitas di luar rumah dibatasi sehingga masyarakat termasuk remaja banyak mengisi aktivitas dengan memanfaatkan media sosial.

Media sosial merupakan media berupa situs ataupun aplikasi yang berbasis teknologi internet, dan bisa dimanfaatkan oleh penggunanya untuk saling terhubung dengan orang lain, baik yang sudah dikenal sebelumnya ataupun tidak. Beragam media sosial yang bisa diakses, diantaranya adalah Facebook, Whatsapp, Instagram, Snapchat, LINE, Google+, Youtube, BBM, Joox, Wattpad, serta Musical.ly. Hasil survei menunjukkan, dari berbagai media sosial yang bisa diakses, terdapat empat media sosial yang paling tinggi intensitas penggunaannya dan banyak dimanfaatkan oleh anak juga remaja Indonesia, yaitu Instagram, Line, Youtube dan Face Book (Triastuti et al., 2017). Penggunaan Instagram dikalangan remaja cukup tinggi karena selain digunakan sebagai sarana mewujudkan eksistensi diri dan membangun komunikasi, Instagram juga dapat membantu remaja menemukan segala informasi yang dibutuhkan termasuk yang berkaitan dengan kesehatan (Mahendra, 2017). Hasil penelitian yang dilakukan terhadap mahasiswa dengan kisaran usia 18-22 tahun menunjukkan bahwa Instagram, WhatsApp, Youtube merupakan media yang paling banyak digunakan, selebihnya Line dan Facebook. Mereka lebih tertarik promosi melalui media sosial terutama instagram, dibandingkan televisi dan media cetak karena promosi menggunakan media sosial tersebut dapat diakses dimana saja dan kapan saja, melalui handphone yang memang selalu dibawa kemana-mana (Purbohastuti, A. $\mathrm{W}, 2017)$. 
Berdasarkan paparan yang disampaikan maka perlu upaya untuk meningkatkan pengetahuan remaja tentang pubertas dengan menggunakan media yang banyak diakses oleh remaja. Instagram sebagai media yang banyak diakses oleh remaja dapat dijadikan alternatif dalam menyampaikan informasi. Sehubungan dengan hal tersebut maka perlu dilakukan kegiatan pengabdian masyarakat dalam bentuk penyampaian informasi melalui siaran langsung dengan menggunakan akun Instagram. Kegiatan ini bertujuan agar remaja memahami definisi pubertas, kapan terjadinya pubertas, perubahan yang umum terjadi selama pubertas serta sikap yang tepat dalam menghadapi pubertas sehingga remaja dapat melalui masa pubertas dengan baik.

\section{METODE}

Kegiatan pengabdian masyarakat yang dilakukan adalah berupa penyampaian informasi melalui media sosial instagram dalam bentuk siaran langsung. Akun yang digunakan untuk melakukan siaran langsung adalah akun instagram stikesrespati. Sasaran kegiatan ini adalah remaja siswa SMP, SMA dan sederajat yang memiliki akses terhadap instagram. Kegiatan dilakukan melalui tiga tahap yaitu: perencanaan, pelaksanaan dan refleksi.

Tahap perencanaan diawali dengan mempersiapkan materi serta melakukan sosialisasi untuk menjaring peserta atau sasaran sebanyak mungkin. Sosialisasi dilakukan satu minggu sebelum pelaksanaan pengabdian dengan cara menyebarluaskan flyer yang berisi informasi kegiatan. Informasi ini disebarluaskan melalui media sosial Facebook, status Whatsapp, serta Instagram dengan menggunakan akun individu maupun institusi. Pelaksanaan kegiatan pengabdian masyarakat diawali dengan pembukaan oleh moderator, dilanjutkan penyampaian materi dan diakhiri dengan menjawab pertanyaan yang disampaikan oleh peserta melalui kolom komentar instagram selama siaran berlangsung. Tahap terakhir dari kegiatan pengabdian adalah melakukan refleksi yaitu analisis respon peserta terhadap kegiatan yang dilakukan dengan cara melihat respon peserta yang dituliskan melalui kolom komentar instagram baik berupa pertanyaan maupun pernyataan dukungan terhadap acara.

\section{HASIL DAN PEMBAHASAN}

Pengabdian masyarakat dilaksanakan pada hari Jumát, 24 Juli 2020, pukul 10.00-11.00 WIB. Kegiatan yang dilakukan sejenis talkshow yang disiarkan secara langsung melalui instagram. Kegiatan ini tidak hanya diikuti oleh siswa SMP, SMA, namun juga oleh mahasiswa dan orang tua. Peserta mendapatkan informasi mengenai kegiatan ini melalui flyer yang telah disebarluaskan seminggu sebelumnya. Penyebaran flyer ini merupakan upaya sosialisasi agar acara yang diselenggarakan mendapat respon dan dapat menjaring sasaran sesuai dengan harapan. Informasi yang disajikan dalam flyer meliputi waktu, topik, pembicara, dan ajakan untuk berpartisipasi dalam kegiatan. Lebih jelasnya dapat dilihat pada gambar 1. berikut ini.

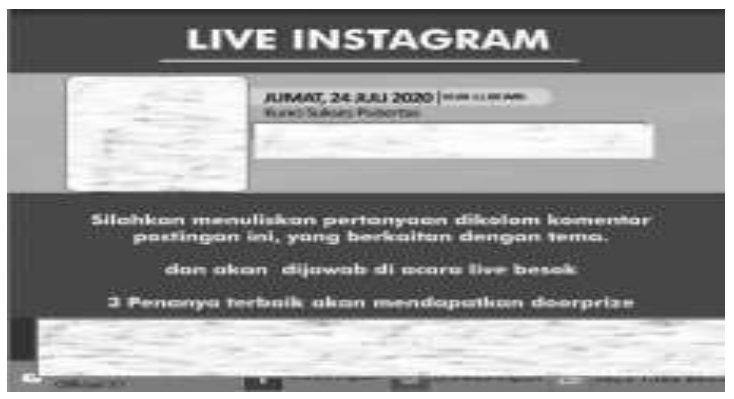

Gambar 1. Flyer Sosialisasi Kegiatan 
Kegiatan dipandu oleh seorang moderator yang merupakan mahasiswa Program Studi S1 Kesehatan Masyarakat. Acara dimulai dengan pembukaan oleh moderator dan dilanjutkan dengan penyampaian materi. Peserta menyimak materi dan dapat langsung memberikan komentar ataupun pertanyaan dengan menuliskannya pada kolom komentar instagram masing- masing. Materi yang disampaikan meliputi: definisi pubertas, kapan pubertas terjadi, ciri-ciri anak yang mengalami pubertas, serta upaya yang dilakukan agar dapat melalui pubertas dengan baik. Pubertas adalah periode seseorang mencapai kematangan fungsi seksual sehingga siap menjalankan fungsi reproduksi (Tim Penulis Komupedia, 2020). Kapan terjadinya pubertas tidak sama pada setiap anak. Ada yang lebih cepat namun ada pula yang lambat. Umumnya dimulai saat berumur 8 hingga 10 tahun dan berakhir lebih kurang di usia 15 hingga 16 tahun. Perempuan biasanya mengalami pubertas lebih cepat yaitu pada rentang usia 10-14 tahun dan pada laki-lakiterjadi pada kisaran usia 12-16 tahun. Pubertas ditandai dengan munculnya ciri atau tanda yang dikenal dengan tanda kelamin primer dan sekunder.

Tanda kelamin primer merupakan keadaan dimana organ seksual baik yang ada di dalam maupun di luar tubuh mulai dapat berfungsi dalam proses reproduksi. Terdapat perbedaan ciri atau tanda kelamin primer dan sekunder pada laki-laki dan perempuan. CIri kelamin primer pada laki-laki adalah keluarnya mani atau yang dikenal dengan mimpi basah, sedangkan pada perempuan ditandai dengan terjadinya haid atau menstruasi. Sebelum kemunculan tanda seks primer akan terlihat adanya tanda seks sekunder baik pada laki-laki maupun perempuan. Tanda seks sekunder adalah munculnya tanda fisik yang tidak berhubungan langsung dengan proses reproduksi namun menjadi tanda spesifik pada lakilaki maupun perempuan dan menjadi identitas peran seksual pada keduanya. Perubahan fisik yang menjadi tanda kelamin sekunder pada laki-laki adalah timbulnya jakun, suara menjadi dalam dan besar, tumbuhnya kumis serta rambut halus pada ketiak, alat kelamin, dan kadang di dada, serta penis tegak berdiri ketika terangsang melihat perempuan. Tanda seks sekunder pada perempuan selain mulai tumbuhnya rambut halus pada ketiak dan alat kelamin juga disertai membesarnya payudara, serta pinggul mulai melebar. (Tim Penulis Komupedia, 2020).

Setelah menyimak materi yang disampaikan, peserta mengajukan pertanyaan yang dituliskan melalui kolom komentar seperti yang terlihat pada tangkapan layar pada gambar 2 berikut ini.
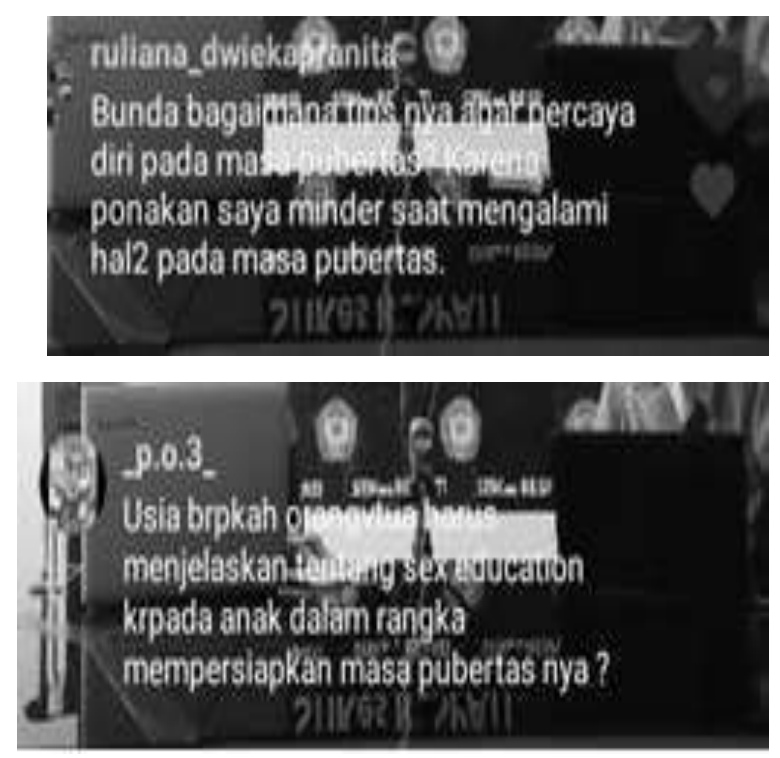
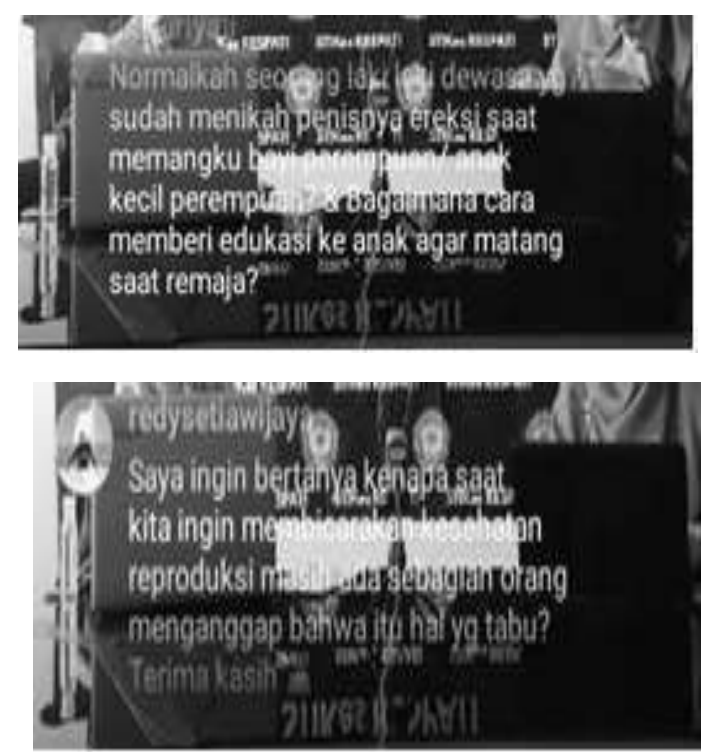

Gambar 2. Tangkapan Layar Pertanyaan yang diajukan Peserta MelaluiKolom Komentar Instagram. 
Pertanyaan mengenai bagaimana membangun rasa percaya diri remaja yang mengalami pubertas berkaitan dengan upaya yang dilakukan agar remaja dapat melalui masa pubertas dengan baik. Perubahan fisik yang dialami pada masa pubertas bisa jadi menimbulkan kebingungan dan muncul berbagai pertanyaan pada diri remaja, seperti: mengapa tubuhnya berubah, mengapa timbul jerawat, mengapa tubuhku menjadi bau, apakah orang lain juga mengalami hal yang sama, dan pertanyaan lainnya. Kondisi ini bisa menyebabkan cemas, bingung, dan malu, sehingga anak kehilangan kepercayaan diri dan menarik diri dari lingkungannya.

Hal ini tidak akan terjadi jika remaja memahami bahwa apa yang dialaminya adalah normal dan pasti dialami oleh setiap orang yang berada dalam fase ini. Anak perlu mendapatkan informasi yang benar tentang pubertas sejak dini. Informasi mengenai tanda pubertas dan segala sesuatu yang terjadi pada masa itu bisa disampaikan orang tua melalui komunikasi langsung dengan anak menggunakan bahasa sederhana yang mudah dipahami. Cara lain yang dapat dilakukan adalah dengan memberikan bacaan mengenai pubertas yang disusun khusus untuk anak-anak.

Pertanyaan kedua mengenai ereksi dan penis berdiri menunjukkan bahwa remaja perlu mengetahui bahwa itu adalah normal dan merupakan salah satu tanda bahwa fungsi seksual sudah berjalan. Remaja perlu mengetahui apa saja yang bisa memicu kondisi itu terjadi, dan diajarkan bagaimana mengontrol aktivitasnya agar tidak menimbulkan rangsangan yang dapat menyebabkan alat kelaminnya menjadi ereksi.

Hal ketiga yang ditanyakan adalah mengenai kapan orang tua melakukan sex education sebagai upaya mempersiapkan anak menghadapi pubertas. Hal yang perlu diingat adalah bahwa pendidikan seks bukan berarti pendidikan yang mengajarkan bagaimana melakukan aktivitas seksual, namun berkaitan dengan organ reproduksi, fungsi seksual dan tanggung jawabnya. Pendidikan seks dilakukan secara bertahap dengan bahasa dan materi yang disesuaikan dengan usia. Pendidikan seks pada anak dapat dilakukan mulai dari usia balita ketika anak mulai menyadari adanya perbedaan organ yang dimiliki laki-laki dan perempuan, tentu dilakukan secara bertahap dan bahasa sederhana yang mudah dipahami. Selanjutnya informasi mengenai pubertas dapat diberikan orang tua kepada anak dimulai secara bertahap ketika sudah terlihat adanya tanda seks sekunder pada anak.

Pertanyaan terakhir adalah mengenai masih adanya anggota masyarakat yang menganggap tabu pembicaraan yang berkaitan dengan seksual. Hal ini menunjukkan bahwa menyampaikan informasi yang berkaitan dengan kesehatan reproduksi perlu dilakukan berkesinambungan untuk meluruskan pemahaman yang keliru. Pendidikan kesehatan reproduksi bukan sekedar membahas aktivitas seksual namun jauh lebih luas, mencakup semua hal yang berkaitan dengan pencapaian derajat kesehatan untuk menunjang fungsi reproduksi secara optimal. Hal yang perlu diketahui remaja diantaranya adalah bagaimana menjaga kesehatan organ reproduksi, perilaku apa saja yang membahayakan kesehatan reproduksi, serta penyakit yang berkaitan dengan kesehatan reproduksi. Remaja perlu memahami kesehatan reproduksi dengan baik agar remaja bertanggung jawab terhadap dirinya sehingga mampu melakukan fungsireproduksi dengan baik ketika waktunya telah tiba. Seringkali karena dianggap hal yang tabu, jorok, atau sebutan lainnya menyebabkan remaja sembunyi-sembunyi mencari informasi dan belum tentu informasi diperoleh dari sumber yang dapat dipertanggungjawabkan dan sesuai dengan kebutuhan usianya.

Pertanyaan dan komentar yang disampaikan peserta dalam kegiatan ini menunjukkan bahwa media sosial instagram bisa dijadikan alternatif dalam menyampaikan informasi yang dibutuhkan masyarakat, khususnya remaja. Waktu satu jam dirasa belum mencukupi untuk bisa menjawab secara tuntas semua pertanyaan yang diajukan. Sehingga waktu kegiatan perlu diperpanjang atau kegiatan dibuat berseri dengan tema yang lebih spesifik sesuai kebutuhan. Remaja membutuhkan sumber informasi yang benar untuk menjawab semua keingintahuan dan juga kebutuhannya. Sumber informasi utama bagi anak remaja adalah 
sekolah dan media sosial, namun tidak semua informasi yang tersedia dan bisa diakses di media sosial adalah benar dan dapat dipertanggungjawabkan (Radjagukguk \& Yayu Sriwartini, 2020). Hal ini mendorong perlunya penyebarluasan informasi secara rutin dengan menggunakan media yang tepat. Media sosial yang bisa diakses secara online dan dapat dijangkau dimana saja dapat menjadi alternatif untuk menyampaikan informasi, terlebih dalam masa pembatasan aktivitas karena pandemi. Efektifitas Instagram sebagai media promosi kesehatan juga terbukti dalam penelitian terhadap mahasiswi nonkesehatan yang menunjukkan terdapat perbedaan pengetahuan, sikap, dan persepsi kegunaan teknologi tentang Sadari, sebelum dan sesudah dilakukan promosi keseha- $\tan$ menggunakan media sosial Instagram (ZA, A. F. S., Sari, N. P., \& Nabila, N, 2019).

\section{Respon Peserta Terhadap Kegiatan Pengabdian Masyarakat Mengenai Pubertas}

Respon peserta terhadap kegiatan sangat bagus, dilihat dari pertanyaan yang diajukan pada kolom komentar juga pernyataan positif yang disampaikan peserta, diantara respon yang diberikan peserta berupa emoticon dan komentar dapat dilihat pada gambar 3 berikut ini.
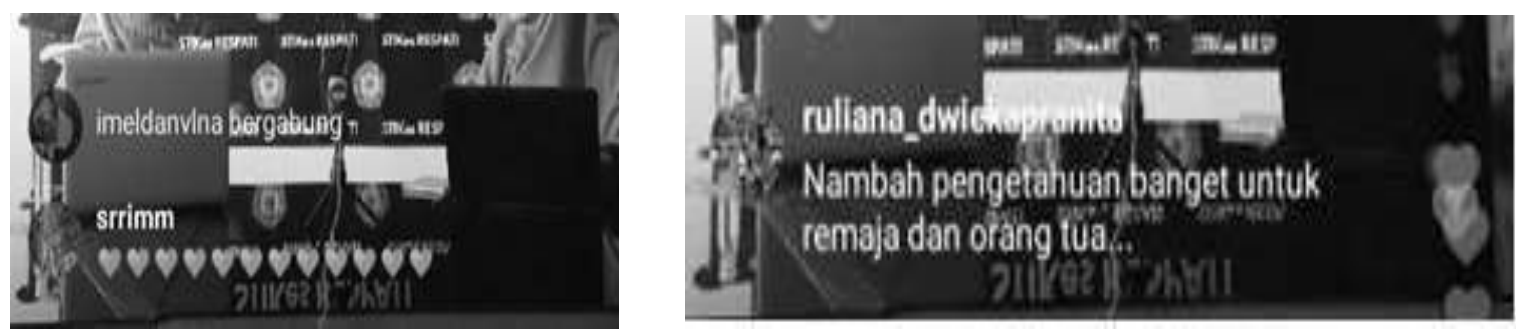

Gambar 3. Dukungan Peserta yang disampaikan Melalui Kolom Komentar Instagram

Salah satu komentar yang diberikan peserta adalah bahwa informasi yang disampaikan dalam kegiatan tersebut bermanfaat tidak hanya bagi remaja namun juga orang tua. Informasi mengenai pubertas sangat diperlukan oleh orang tua yang memiliki anak usia remaja agar dapat mendampingi anak melalui fase ini dengan baik. Keluarga dalam hal ini orang tua memberikan peranan yang signifikan terhadap peningkatan perilaku adaptif remaja pada masa pubertas (Triyanto et al., 2014). Penelitian terhadap siswa di SMPN 2 Depok Sleman juga menunjukkan bahwa terdapat hubungan yang signifikan antara dukungan keluarga dengan citra tubuh dalam menghadapi masa pubertas. Orang tua merupakan sumber informasi utama bagi anak, sehingga komunikasi orang tua sangat penting dalam rangka pembentukan karakter anak (Radjagukguk \& Yayu Sriwartini, 2020). Mengingat pentingnya peran orang tua bagi remaja maka selanjutnya dapat dilakukan kegiatan yang melibatkan orang tua juga remaja dengan pemilihan tema disesuaikan dengan kebutuhan.

Secara keseluruhan kegiatan berjalan dengan lancar dengan adanya kerja sama yang baik antara moderator, pembicara, serta didukung oleh ketersediaan sarana yang menunjang, seperti ketersediaan ruangan yang nyaman untuk melakukan pengambilan gambar, koneksi internet yang baik, serta tersedianya kamera yang digunakan dalam pengambilan gambar selama kegiatan berlangsung.

\section{KESIMPULAN}

Kesimpulan dari kegiatan pengabdian masyarakat dengan tema "Pemanfaatan Media Sosial Instagram untuk Meningkatkan Pengetahuan Remaja tentang Pubertas", adalah sebagai berikut:

a. Kegiatan yang dilakukan dalam bentuk penyampaian informasi menggunakan media sosialinstagram dengan melakukan siaran langsung. 
b. Materi yang disampaikan meliputi definisi pubertas, usia terjadinya pubertas, ciri-ciri pubertas, serta upaya yang dilakukan agar dapat melalui pubertas dengan baik.

c. Sambutan peserta terhadap kegiatan sangat baik, dengan memberikan komentar berupa dukungan terhadap kegiatan serta pertanyaan .

d. Kegiatan yang dilakukan dapat membantu remaja memperoleh informasi yang tepat tentangpubertas.

e. Selain kepada remaja, informasi tentang pubertas perlu diseberluaskan juga kepada orang tuaagar bisa mendampingi anaknya yang berusia remaja melalui pubertas dengan baik.

f. Waktu pelaksanaan kegiatan selama 60 menit dirasa masih kurang sehingga untuk kegiatan sejenis diperlukan waktu lebih lama atau dibuat berseri dengan tema yang lebih spesifik.

g. Penyebarluasan informasi melalui media sosial yang banyak diakses oleh remaja perlu dilakukan secara intensif, terutama di masa pandemi dimana aktivitas remaja dibatasi dan intensitas penggunaan media sosial lebih tinggi.

\section{UCAPAN TERIMA KASIH}

Penulis mengucapkan terima kasih kepada Lembaga Penelitian dan Pengabdian Masyarakat (LPPM) Sekolah Tinggi Ilmu Kesehatan Respati yang telah mendorong terlaksananya kegiatan pengabdian ini. Selain itu penulis juga mengucapkan terima kasih kepada tim Informasi dan Teknologi (IT) STIKes Respati yang telah mempersiapkan dan memastikan ketersediaan sarana pendukung sehingga kegiatan dapat terselenggara dengan baik.

\section{DAFTAR PUSTAKA}

Buzarudina, F. (2013). Efektivitas Penyuluhan Kesehatan Reproduksi Remaja Terhadap Tingkat Pengetahuan Siswa Sman 6 Kecamatan Pontianak Timur. Jurnal Mahasiswa $\begin{array}{lllll}P S P D & F K & \text { Universitas } & \text {..., }\end{array}$ http://jurnal.untan.ac.id/index.php/jfk/article/view/3783

Dewi, S. C., Istianah, U., \& Hendarsih, S. (2019). Peningkatan Kemampuan Menjalani Masa Pubertas Melalui Penyuluhan Kesehatan Reproduksi Pada Remaja Putri Kelas VIII Di SMP N 2 Gamping Sleman. Caring :Jurnal Keperawatan, 8(2),95-103. https://ejournal.poltekkesjogja.ac.id/index.php/caring

Juliana, J., Ibrahim, I., \& Sano, A. (2014). Konsep Diri Remaja pada Masa Pubertas dan Implikasinya terhadap Layanan Bimbingan dan Konseling. Jurnal Konseling Dan Pendidikan, 2(1), 1. https://doi.org/10.29210/111300

Mahendra, B. (2017). Eksistensi Sosial Remaja Dalam Instagram (Sebuah Perspektif Komunikasi). Jurnal Visi Komunikasi, 16(01), 151-160.

Notoatmodjo, S. (2012). Promosi Kesehatan dan Perilaku Kesehatan. Jakarta: Rineka Cipta.

Purbohastuti, A. W. (2017). Efektivitas Media Sosial Sebagai Media Promosi. Tirtayasa Ekonomika, 12(2), 212-231.

Radjagukguk, D. L., \& Yayu Sriwartini. (2020). Peran Orangtua Menyikapi Pornografi Pada Remaja Melalui Komunikasi Efektif. Dinamisia : Jurnal Pengabdian Kepada Masyarakat, 4(2), 354- 363. https://doi.org/10.31849/dinamisia.v4i2.3765

Sarwono, S. W. (2016). Psikologi Remaja. Jakarta: Rajagrafindo Persada. 
Subekti, N. M., Prasetyanti, D. K., \& Nikmah, A. N. (2020). Gambaran Faktor yang Mempengaruhi Kesiapan Dalam Menghadapi Pubertas Pada Remaja. Jurnal Mahasiswa Kesehatan, 1(2).

Tim Penulis Komupedia. (2020). Handbook Pubertas Muslimah (3rd ed.). Tangerang: AhlanPustaka Umat.

Triastuti, E., Andrianto, D., \& Nurul, A. (2017). Kajian Dampak Penggunaan Media Sosial Bagi AnakDan Remaja. In Puskakom.

Triyanto, E., Setiyani, R., \& Wulansari, R. (2014). Pengaruh Dukungan Keluarga dalam Meningkatkan Perilaku Adaptif Remaja Pubertas. Jurnal Keperawatan Padjadjaran, v2(n1), 1-9. https://doi.org/10.24198/jkp.v2n1.1

ZA, A. F. S., Sari, N. P., \& Nabila, N. (2019). Promosi Kesehatan "Sadari" Menggunakan Instagram pada Mahasiswi Non Kesehatan Universitas Andalas. Media Kesehatan Masyarakat Indonesia, 15(3), 253-263. 